\title{
An investigation of the toxic effects of a herbal formulation with anti-carcinogenic properties
}

\author{
'S. S. Iddamaldeniya', S. M. D. N. Wickramașinghe', M. I. Thabrew², N. Ratnatunge3, \\ M. G. Thammitiyagodage ${ }^{4}$
}

The Ceylon Journal of Medical Science 2005; 48: 13-23

\begin{abstract}
A decoction prepared from a mixture of Nigella sativa seeds, Hemidesmus indicus root, and Smilax glabra rhizome used by some traditional medical practitioners in Sri Lanka is considered to be useful for the treatment of cancer patients. However, there is a lack of information about any adverse effects of this decoction. Experiments were carried out using Wistar rats and ICR mice as the experimental model, to evaluate any adverse effects mediated by the above decoction.
\end{abstract}

Results of the investigations showed that administration of the decoction (at doses of $4 \mathrm{~g} / \mathrm{kg}$ body weight/day and $6 \mathrm{~g} / \mathrm{kg}$ body weight/day) to rats for three months had no adverse effects on the liver functions (as assessed by its effects on serum levels of alanine and aspartate aminotransferase and alkaline phosphatase) or haematological parameters (red blood cell count, white blood cell count, haemoglobin concentration, packed cell volume, mean corpuscular haemoglobin, mean corpuscular volume and mean corpuscular haemoglobin concentration). No significant pathological changes were observed in sections of the major body organs (liver, heart, lungs, stomach, duodenum and kidney) of animals treated with the decoction for three months.

The investigations also demonstrated that the decoction did not have anti-ovulatory, anti-implantation, spermicidal activity. An attempt to determine the $\mathrm{LD}_{50}$ concentration was unsuccessful. Even at a dose equivalent to 40 times $(240 \mathrm{~g} / \mathrm{kg} /$ day) the normal therapeutic dose $(6 \mathrm{~g} / \mathrm{kg} /$ day), no mortality or other toxic symptoms (loss of consciousness, salivation, muscle tremor, incoordination, hyperaesthesia, polyuria, anuria, polydipsea, defecation, piloerection, changes in locomotor activity, changes in posture, ataxia and loss of reflexes) were observed. Three month treatment with the decoction also did not produce any changes in average feed consumption, average body weight: liver weight ratios, or the general behaviour of the animals.

Key words: Rats; Ayurveda decoction, hepatotoxicity, reproduction parameters, anti-carcinogenic.

\section{Introduction}

A decoction prepared from a mixture of Nigella satvia Linn (Family: Ranunculaceae,

1. Department of Biochemistry, Faculty of Medical Sciences, University of Sri Jaynanardenepura, Gangodnzila, Nugegoda.

2. Department of Biochemistry and Clinical Chemistry, Faculty of Medicine, University of Kelaniyn, Ragama.

3. Department of Pathology, Faculty of Medicine, University of Peradeniya, Peradeniya.

4. Animal Centre, Medical Research Institute, Colombo 8.

* Author for correspondence E-mail: drsamsi2003@yahoo.com 
S: Kaluduru, T: Karungiragam) seeds, Hemidesmus indicus (L) R.Br. (Family: Asclepiadaceae, S: Iramusu, T: Arakkan) root, and Smilax glabra Rox B. (Family: Liliaceae, S: Cheena Ala) rhizome is used by some traditional medical practitioners in Sri Lanka for treatment of cancer (personal communication, Ayurveda Dr. N. Jayathilake, Physician, Bandaranaike Memorial Ayurveda Research Institute (BMARI), Navinna, Maharagama). Investigations with Wistar rats have shown that the decoction can significantly protect against diethylnitrosamine-induced hepatocarcinogenesis (1).

The value of any anti-carcinogenic agent would depend not only on its therapeutic efficacy but also on its lack of toxicity. Any anti-cancer drug with therapeutic value would have to be administered over a relatively long period. It must therefore be free of acute and chronic adverse effects. Therefore, a study was undertaken in rats, to evaluate any possible toxic effects mediated by long term ( 3 months) administration of the decoction comprising of Nigella sativa seeds, Hemidesmus indicus root, and Smilax glabra rhizome.

\section{Material and Methods}

\section{Experimental animals}

In all experiments Wistar rats (8 week old littermates, $190 \pm 10 \mathrm{~g})$ and ICR mice (20 \pm $5 \mathrm{~g}$ ) were used and maintained in a temperature-controlled room $\left(25^{\circ} \mathrm{C} \pm 2{ }^{\circ} \mathrm{C}\right)$ under 12 hours light/dark cycle (dark phase 6 p.m. to 6 a.m.). They were fed with a standard laboratory diet containing $19 \%$ crude proteins, $3.8 \%$ fiber and $4400 \mathrm{kcal}$ of energy, prepared by the Medical Research Institute, Sri Lanka, based on a formula recommended by the $\mathrm{WHO}$, and water ad libitum (2).

\section{Plant material}

Dried rhizome of Smilax glabra, dried seed of Nigella sativa and dried root of Hemidesmus indicus were purchased locally, and identities were confirmed by $\mathrm{Mr}$. Gunarathne Silva, Botanist, BMARI, Navinna, Maharagama, Sri Lanka. Voucher samples were placed at the BMARI.

\section{Preparation of the decoction}

The plant decoction was prepared according to the method recommended by traditional medical practitioners for the administration to cancer patients (personal communication, Ayurveda Dr. N. Jayathilake). Twenty grams each of Nigella sativin (dried seeds), Hemidesmus indicus (dried root, cut into small pieces) and Smilax glabra (dried rhizome, cut into small pieces) were mixed and boiled in 1.6 litres of distilled water and final volume was reduced to $200 \mathrm{ml}$ by boiling over 3 hours.

\section{Dosage and administration of decoction}

The decoction was administered to rats using a Sondi needle by gastric gavage method. The effect of two doses of the decoction was studied. Dose 1 was $4 \mathrm{~g} / \mathrm{kg}$ body weight/ day. This dose corresponds to the normal therapeutic dose administered to adult humans as calculated based on the relative surface areas of human and rat. Dose 2 provided $6 \mathrm{~g}$ decoction $/ \mathrm{kg}$ body weight/day.

Yield of the decoction was $0.33 \mathrm{~g} / \mathrm{ml}$. Calculation of the volume of decoction that should be given was done according to the required dose of the decoction and the body weights of rats and mice $(190 \pm 10 \mathrm{~g}$ and $20 \pm$ $5 \mathrm{~g}$ respectively). Whenever, the calculated volume exceeded the maximum volume that could be given to a rat or mouse $(5 \mathrm{ml} / \mathrm{rat}$ or $1 \mathrm{ml} /$ mouse), the calculated volume was heated over burner and reduced down. 


\section{Determination of $\mathbf{L D}_{50}$}

To determine the dose of the decoction that would cause the death of $50 \%$ of the test animals $\left(L_{50}\right), 20$ female and 20 male ICR mice were randomly divided into four groups of ten each ( 5 females and 5 males). Groups 1 to 4 were orally fed with a single dose of the decoction $6 \mathrm{~g} / \mathrm{kg}$ body weight/ day, $60 \mathrm{~g} / \mathrm{kg}$ body weight/day, $120 \mathrm{~g} / \mathrm{kg}$ body weight/day and $240 \mathrm{~g} / \mathrm{kg}$ body weight/day respectively. After single dosing with different concentrations of the decoction, mice were observed for seven days for any mortality, loss of consciousness, hyperaesthesia, salivation, muscle tremor and incoordination, polyuria, anuria, polydipsea, defecation, piloerection, and changes in posture, ataxia and loss of reflexes.

\section{Effects on haematological parameters}

Male Wistar rats ( $n=18,8$ weeks of age) were randomly divided into three groups of six each. Group 1 was treated with $4 \mathrm{~g} / \mathrm{kg}$ body weight/day of the decoction for thirty days; rats in group 2 were treated with $6 \mathrm{~g} /$ kg body weight/day for thirty days; Group 3 (control) was fed with distilled water (3 $\mathrm{ml}$ ) for thirty days. On the 31st day, blood was collected by tail vein bleeding for assessment of effects on haematological parameters. The white blood cell (WBC) count and differential count (DC), red blood cell (RBC) count, packed cell volume (PCV) and haemoglobin $(\mathrm{Hb})$ concentrations were determined according to the methods described by the International Committee for Standardization in Haemotology (3). Using the above data, mean corpuscular volume (MCV), mean corpuscular haemoglobin $(\mathrm{MCH})$, and mean corpuscular haemoglobin concentration (MCHC) were calculated.

\section{Effects on serum enzyme levels}

Above experiment was continued for a further two months. At the end of the third month, rats were given ether anaesthesia and blood was collected by cardiac puncture. During this procedure the animal died and was subjected to an autopsy. Serum was analyzed for alanine aminotransferase (ALT), aspartate aminotransferase (AST) and alkaline phosphatase (ALP) according to methods described in commercially available reagent kits marketed by DMA Inc, USA.

\section{Assessment of histological changes}

At autopsy samples were taken from the heart, lungs, liver, kidneys, duodenum and stomach, and placed in $10 \%$ buffered formalin (sample volume: formalin volume $=1: 8$ ) for histopathological studies. Histological changes (cell swelling, fatty change, granular and vacuolar degeneration and nuclear changes) were assessed by light microscopic examination of sections from the above organs stained with haemotoxylin and eosin.

Effects on body weight gain, feed consumption ratio and body weight: liver weight ratio

Throughout the above experiment, the daily feed consumption and weekly body weight gain of each rat was recorded and average feed consumption and body weight gain was calculated. Before samples were taken from liver for histological examination, weight of each liver was recorded and body weight: liver weight ratio was calculated.

\section{Effects on reproductive ability}

Studies were done to determine effects of the decoction on reproductive ability of both 
male and female rats. In female rats, effects on ovulatory activity and implantation were determined while in male rats effect on spermicidal activity was determined.

\section{Effects on ovulatory activity}

Wistar female rats $(n=18,14$ to 16 weeks of age) with normal oestrus cycle (average 4-6 days of pro-oestrus, oestrus, metoestrus and dioestrus) were divided into three groups of six each. Group 1 and 2 were given decoction doses $4 \mathrm{~g} / \mathrm{kg}$ body weight/day and $6 \mathrm{~g} / \mathrm{kg}$ body weight/day respectively for 18 days. Group 3 was considered as the control group and $3 \mathrm{ml}$ of distilled water was given daily for 18 days. Vaginal smears were examined daily to check the stage of oestrus they were in. Persistent dioestrus, non-cyclic and lengthy oestrus cycles were considered as toxic signs. Different stages of the oestrus cycle were determined according to Soejarto et al (4).

\section{Effects on implantation}

Regularly cyclic female virgin rats (14 to 16 weeks of age) were mated. Presence of copulation plugs or sperms in the vaginal smear on the following morning were regarded as confirmation of mating. The day copulation plugs or sperms appeared was assumed the day one of pregnancy. Pregnant female rats $(n=15)$ were randomly divided into three groups of five each. Groups 1 and 2 were given decoction doses $4 \mathrm{~g} / \mathrm{kg}$ body weight/day and $6 \mathrm{~g} / \mathrm{kg}$ body weight/day respectively from days 1 to 7 of pregnancy. Group 3 was given $3 \mathrm{ml}$ of distilled water from days 1 to 7 . Autopsies were performed on the 10th day and the number of implantation sites, the number of live/dead foetuses and the number of corpora luten of pregnancy were recorded (4).

\section{Effects on spermicidal activity}

Wistar male rats $(n=18,14$ to 16 weeks of age) were randomly divided into three groups of six each. Groups 1 and 2 were given the decoction in doses of $4 \mathrm{~g} / \mathrm{kg}$ body weight/day and $6 \mathrm{~g} / \mathrm{kg}$ body weight/day respectively, for three months. Group 3 was considered as the control group and $3 \mathrm{ml}$ distilled water was given for three months. At the end of treatment, each male rat was mated individually with a female rat in oestrus (14 to 16 weeks of age). Presence of copulation plugs or sperms in the vaginal smear on the following morning were regarded as evidence of mating. After 18 to 21 days of gestation period, the number of mated female rats: number of unmated female rats, number of female rats who delivered pups, and the litter size of each female rat were recorded. All these parameters were considered as a reflection of the reproductive ability of the particular male rat, which mated each female rat (4).

\section{Statistical analysis}

Results are expressed as mean \pm standard error of mean (mean \pm SEM). Statistical analysis was done using the student's t test. $P<0.05$ was considered as significant.

\section{Results}

\section{$\mathrm{LD}_{\text {s0 }}$ determination}

No deaths were observed in the seven days following a single oral administration of several different doses of the decoction $(60$, 120 , and $240 \mathrm{mg} / \mathrm{kg}$ body weight). Even the highest dose $(240 \mathrm{mg} / \mathrm{kg}$ body weight did not produce any apparent adverse effects. Therefore, these results did not allow the calculation of the $\mathrm{LD}_{50}$. 


\section{Effects on haematological parameters}

Table 1 summarizes the results obtained with respect to the effects of treatment with the decoction for 30 days on haematological parameters. No significant differences were observed between controls and treated rats concerning the parameters measured (P>0.05).

\section{Serum enzyme levels}

Table 2 summarizes the results found on analysis of ALT, AST and ALP after three months of decoction treatment. No significant differences were observed between controls and treated rats concerning the parameters measured $(\mathrm{P}>0.05)$.
Effects of the decoction on feed consumption, body weight gain, and body weight: liver weight ratio

Treatment with the decoction for three months did not alter average feed consumption, average body weight gain or body weight: liver weight ratio of the test animals. Results are shown in Table 3. No significant differences were seen between treated and the control group of rats $(P>0.05)$.

\section{Histopathology}

No significant histological changes were observed in the heart, lung, liver, stomach, duodenum, and kidney of test animals when compared with the controls.

Table 1. A comparison of haematological variables of rats treated with the decoction for one month

\begin{tabular}{lccc}
\hline Variable & $\begin{array}{c}\text { Group 1 (decoction } \\
\text { dose } 4 \mathrm{~g} / \mathrm{kg} / \text { day) }\end{array}$ & $\begin{array}{c}\text { Group 2 (decoction } \\
\text { dose 6g/kg/day) }\end{array}$ & $\begin{array}{c}\text { Group 3 (distilled } \\
\text { water control) }\end{array}$ \\
\hline PCV\% & $52.8 \pm 05$ & $52.2 \pm 0.4$ & $53.3 \pm 0.4$ \\
$\mathrm{Hb}(\mathrm{g} / \mathrm{dl})$ & $15.9 \pm 0.4$ & $15.5 \pm 0.4$ & $16.3 \pm 0.6$ \\
$\mathrm{RBC}\left(\times 10^{6} \mathrm{cells} / \mathrm{mm}^{3}\right)$ & $8.5 \pm 0.4$ & $8.6 \pm 0.4$ & $8.4 \pm 0.3$ \\
WBC $\left(\times 10^{3} \mathrm{cells} / \mathrm{mm}^{3}\right)$ & $17.8 \pm 0.3$ & $14.8 \pm 0.6$ & $15.6 \pm 1.2$ \\
Neutrophils $\left(\times 10^{3} \mathrm{cells} / \mathrm{mm}^{3}\right)$ & $20.7 \pm 1.2$ & $19.5 \pm 1.5$ & $20.8 \pm 0.3$ \\
Eosinophils $\left(\times 10^{3} \mathrm{cells} / \mathrm{mm}^{3}\right)$ & $1.0 \pm 0.3$ & $2.0 \pm 0.4$ & $2.0 \pm 0.3$ \\
Basophils $\left(\times 10^{3} \mathrm{cells} / \mathrm{mm}^{3}\right)$ & $\mathrm{Nil}$ & $\mathrm{Nil}$ & $\mathrm{Nil}$ \\
Monocytes $\left(\times 10^{3} \mathrm{cells} / \mathrm{mm}^{3}\right)$ & $1.7 \pm 0.2$ & $2.5 \pm 0.2$ & $2.8 \pm 0.5$ \\
Lymphocytes $\left(\times 10^{3} \mathrm{cells} / \mathrm{mm}^{3}\right)$ & $77.2 \pm 1.3$ & $74.0 \pm 2.2$ & $86.8 \pm 0.8$ \\
MCV $(\mathrm{fl})$ & $63.7 \pm 2.0$ & $60.8 \pm 1.5$ & $64.4 \pm 2.4$ \\
MCH $(\mathrm{pg})$ & $18.9 \pm 0.8$ & $18.0 \pm 0.3$ & $19.6 \pm 0.5$ \\
$\mathrm{MCHC}(\mathrm{g} / \mathrm{dl})$ & $31.0 \pm 0.3$ & $29.1 \pm 0.8$ & $30.3 \pm 0.7$ \\
\hline
\end{tabular}

Data shown are the mean \pm SEM of 10 determinants

None of the results were significantly different from control 
Table 2. Effects of decoction on serum enzyme levels after three months of treatment

\begin{tabular}{lccc}
\hline Group & ALT (IU/U) & AST (IU/L) & ALP (IU/L) \\
\hline Group 1 & $23.6 \pm 1.4$ & $74.9 \pm 6.0$ & $67.8 \pm 7.2$ \\
Group 2 & $18.4 \pm 1.3$ & $69.1 \pm 6.3$ & $73.0 \pm 5.1$ \\
Group 3 & $19.4 \pm 1.4$ & $78.0 \pm 6.9$ & $84.0 \pm 3.0$ \\
\hline
\end{tabular}

Data shown are the mean \pm SEM of 10 determinants

Group 1: Decoction dose $4 \mathrm{~g} / \mathrm{kg}$ body weight/day

Group 2: Decoction dose $6 \mathrm{~g} / \mathrm{kg}$ body weight/day

Group 3: Control

None of the results were significantly different from control

Table 3. Effects of decoction on average feed consumption, average body weight gain and body weight: liver weight ratio

\begin{tabular}{lllc}
\hline Group & $\begin{array}{c}\text { Average feed } \\
\text { consumption } \\
(\mathrm{g} / \text { day/rat })\end{array}$ & $\begin{array}{c}\text { Average body } \\
\text { weight gain } \\
(\mathrm{g} / \text { day } / \text { rat })\end{array}$ & $\begin{array}{c}\text { Body weight: liver } \\
\text { weight }\end{array}$ \\
\hline Group 1 & $12.0 \pm 1.8$ & $1.6 \pm 0.1$ & $1.0: 0.03$ \\
Group 2 & $11.5 \pm 1.5$ & $1.6 \pm 0.1$ & $1.0: 0.03$ \\
Group 3 & $10.7 \pm 1.4$ & $1.6 \pm 0.3$ & $1.0: 0.03$ \\
\hline
\end{tabular}

Data shown are the mean \pm SEM of 10 determinants

Group 1: Decoction dose $4 \mathrm{~g} / \mathrm{kg}$ body weight/day

Group 2: Decoction dose $6 \mathrm{~g} / \mathrm{kg}$ body weight/day

Group 3: Control

None of the results were significantly different from control 
Effects on reproductive ability

Anti-ovulatory activity

As can be seen in Table 4, treatment with either of the two doses of decoction did not result in any alteration of the oestrus cycle, nor did the animals become persistently dioestrus.

\section{Effects on implantation}

Table 5 shows that oral administration of $4 \mathrm{~g} / \mathrm{kg}$ body weight/day of decoction did not significantly alter the number of pregnant animals, the number of non pregnant animals, the number of implantation sites, the number of corpora lutea of pregnancy and the number of resorptions per total number of implantation sites ( $P>0.05)$.

\section{Spermicidal activity}

Results obtained are presented in Table 6. No significant differences were found after treatment with the decoction for three months in the number of pups delivered, or the litter size $(P>0.05)$. The decoction therefore does not appear to have any significant effect on spermicidal activity of male rats.

Table 4. Effects of decoction on oestrus cycle

\begin{tabular}{lccc}
\hline Group & $\begin{array}{c}\text { Persistent } \\
\text { dioestrus (number) }\end{array}$ & $\begin{array}{c}\text { Regularly cyclic } \\
\text { (number) }\end{array}$ & $\begin{array}{c}\text { Duration of the } \\
\text { oestrus (days) }\end{array}$ \\
\hline Group 1 & Nil & $6.0 \pm 0.0$ & $4.0 \pm 0.0$ \\
Group 2 & Nil & $6.0 \pm 0.0$ & $4.0 \pm 0.0$ \\
Group 3 & Nil & $6.0 \pm 0.0$ & $4.0 \pm 0.0$ \\
\hline
\end{tabular}

Data shown are the mean $\pm S E M$ of 10 determinants

Group 1: Decoction dose $4 \mathrm{~g} / \mathrm{kg}$ body weight/day

Group 2: Decoction dose 6g/kg body weight/day

Group 3: Control

None of the results were significantly different from control 
Table 5. Effects of decoction on implantation

\begin{tabular}{lccc}
\hline Variable & Group 1 & Group 2 & Group 3 \\
\hline $\begin{array}{l}\text { Pregnancy rate } \\
\begin{array}{l}\text { Number of } \\
\text { implantation sites }\end{array}\end{array}$ & $4 / 5(80 \%)$ & $3 / 5(60 \%)$ & $4 / 5(80 \%)$ \\
$\begin{array}{l}\text { Number of live } \\
\text { foetuses }\end{array}$ & $13.2 \pm 2.1$ & $13.6 \pm 1.5$ & $14.0 \pm 1.4$ \\
$\begin{array}{l}\text { Number of corpora } \\
\text { lutea of pregnancy }\end{array}$ & $14.8 \pm 0.5$ & $13.3 \pm 1.2$ & $13.5 \pm 1.0$ \\
$\begin{array}{l}\text { Number of } \\
\text { resorptions/total } \\
\text { implantation sites }\end{array}$ & $2 / 53$ & $1 / 40 \pm 1.7$ & $14.2 \pm 1.2$ \\
\hline
\end{tabular}

Data shown are the mean \pm SEM of 10 determinants

Group 1: Decoction dose $4 \mathrm{~g} / \mathrm{kg}$ body weight/day

Group 2: Decoction dose 6g/ $\mathrm{kg}$ body weight/day

Group 3: Control

None of the results were significantly different from control

Table 6. Effects of decoction on spermicidal activity

\begin{tabular}{ccc}
\hline Group & $\begin{array}{c}\text { Number who } \\
\text { delivered }\end{array}$ & Litter size \\
\hline Group 1 & $6.0 \pm 0.0$ & $11.8 \pm 0.4$ \\
Group 2 & $6.0 \pm 0.0$ & $12.0 \pm 1.4$ \\
Group 3 & $6.0 \pm 0.0$ & $12.0 \pm 0.6$ \\
\hline
\end{tabular}

Data shown are the mean \pm SEM of 10 determinants

Group 1: Decoction dose 4g/kg body weight/day

Group 2: Decoction dose 6g/kg body weight/day

Group 3: Control

None of the results were significantly different from control 


\section{Discussion}

For a herbal formulation to be of value clinically it should not only have the required pharmacological activities but must also be free of any serious adverse effects. Although a decoction of $N$. sativa, $H$. indicus and $S$. glabra has been in use for many years for the treatment of cancer patients, its possible adverse effects have not been evaluated in a scientifically controlled manner. Studies by other workers has shown that there are some medicinal plant extracts that contain toxic components, which have the potential to produce serious adverse reactions $(5,6,7)$. Many of the plants used in the preparation of herbal teas, particularly Senecio, Crotolarin and Heliotropium species contain pyrollizidine alkaloids that can be hepatotoxic (8). Similarly, some herbal extracts sold in capsule form in the market as stress relievers (eg. Kalms, Neurolex) have been reported to produce severe liver damage in people who consume these extracts (6). It is therefore very important to carry out scientifically controlled studies on theses remedies to ensure that they are safe and will not produce any serious adverse effects.

According to Arsecularatne et al (9) and Tennekoon et al (10), $H$. indicus and $N$. sativa respectively, contain hepatotoxic components. However, in the present study, despite the extensive toxicity investigations, the tested decoction did not produce any significant toxicological effects when administered in the doses recommended by the traditional medical practitioners. A recent study also showed that $N$. sativa does not have any toxicological properties (11). The explanation for the discrepancy could be that the dose of $N$. sativa used by Tennekoon et al was about four times higher than that used as the highest dose of decoction in the present study $(2 \mathrm{~g} / \mathrm{kg} /$ day). Arsecularatne et al 1985 incorporated powdered $H$. indicus directly into the rat feed whereas in the present investigation, researchers fed the decoction containing $H$. indicus orally. Whether these two types of feeding have any difference regarding the constituents is unclear.

According to Nagaratnam et al (12), alkaloids in various decoctions consumed by people in Sri Lanka may cause liver damage, leading to hepatocellular carcinoma. However, the decoction used in the present study protected against chemically induced hepatocarcinogenesis (1) and did not cause any liver damage, as assessed by lack of alterations in the serum enzyme levels AST, ALT and ALP and liver histopathology, even after three months of continuous treatment. Whether the difference in effects is due to species difference or due to difference in the chemical components of the decoction used in the study requires investigation.

Zaoui et al (13) had reported that fixed oil of $N$. sativa could cause leukocyte counts to decrease and PCV and haemoglobin levels to increase in rats. However, present study with decoction containing $H$. indicus and $S$. glabra in addition to $N$. sativn, revealed that none of the haematological parameters that were tested were altered even after three months of continuous treatment. The same investigation by Zaoui et al also showed that fixed oil of $N$. sativa caused a slowing of body weight gain in rats. However, in the present study no changes in body weight gain was observed during the experimental period. Whether these differences are due to protective effects of components in $\mathrm{H}$. indicus and S. glabra is not clear.

It is well known that several commonly used plant based drugs have adverse effects on fertility, as well as teratogenic effects (14). 
Morphine and caffeine given to male rats before mating decreases the number of pups and frequently lead to death (15). In the present study where the effects of the decoction on ovulatory activity, implantation and spermicidal activity were investigated, no alterations were found in the length of oestrus cycle, the interval between cycles, gestation period and number of pups per litter or any other parameter investigated.

The general well being of the animals also did not change. All the animals remained in good health throughout the experimental period. This study has shown that this decoction did not produce any significant adverse effects on body systems in rats and mice.

\section{Acknowledgements}

We thankfully acknowledge the research grant from National Science Foundation, Sri Lanka and Ayurveda Dr. N. Jayathilake for providing the recipe for preparation of the decoction. Authors also wish to thank Dr. S. Jayasekera and Mr. Sarath Sisira Kumara, Animal Centre, MRI, Colombo and Ms. Sujatha Ramadasa, Department of Pathology, Faculty of Medicine, University of Peradeniya, for the support provided.

\section{References}

1. Iddamaldeniya S.S., Wickremasinghe N., Thabrew M.I., Ratnatunge N., Thammitiyagodage M.G. Protection against diethylnitrosamine-induced hepatocarcinogenesis by an indigenous medicine comprised of Nigella sntiva, Hemidesmus indicus, and Smilax glabra: a preliminary study. Journal of Carcinogenesis 2003; 2: 6.
2. Sabourdy M.A. Breeding and care of laboratory animals, Volume 1, pp. 18-19. WHO 1988, Health Laboratory Technology Unit, Geneva, Switzerland.

3. International Committee for Standardization in Haematology. Recommendations for reference method for determination of centrifugation of packed cell volume of blood. Journal of Clinical Pathology 1980; 33: 1.

4. Soejarto D.D., Bingel A.S., Slaytor M., Farnsworth N.R. Fertility regulating agents from plants. Bulletin of the World Health Organization 1978; 56: 343-352.

5. Penn R.G.C. Adverse reactions to herbal medicines. Australian Prescriber 1988; 2: 15-18.

6. McGregor F.B., Abernethy V.E., Dahabra S., Cobden I., Hades P.C. Hepatotoxicity of herbal remedies. British Medical Journal 1989; 299: 1156-1158.

7. Maruo V.M., Soares M.R., Bernardi M.M., Spinosa H.S. Embryotoxic effects of Solanum lycocarpum St. Hill fruit consumption during preimplantation and organogenesis in rats. Neurotoxicology and Teratology 2003;25: 627-631.

8. Arseculeratna S.N., Gunathilake A.A.L., Panabokke R.G. Studies on medicinal plants of Sri Lanka: occurrence of pyrrolizidine alkaloids and hepatotoxic properties in some traditional medicinal herbs. Journal of Ethnopharmacology 1981; 4: 159-177.

9. Arseculeratna S.N., Gunathilake A.A.L., Panabokke R.G. Studies on medicinal 
plants of Sri Lanka Part 14: Toxicity of some traditional medicinal herbs. Journal of Ethnopharmacology 1985; 13: 323-335.

10. Tennekoon K.H., Thyaparam J., Kurukulasooriya A.P., Karunanayake E.H. Possible hepatotoxicity of Nigella sativa and Dregea volubilis leaves. Journal of Ethnopharmacology 1990;31: 283-289.

11. Ali B.H., Blunden G. Pharmacological and toxicological properties of Nigella sativa. Phytotherapy Research 2003; 17 : 299-305.

12. Nagaratnam N., Ramachandran V., Jiffrey A.J., Bhuvanendran N. Primary liver cancer in Sri Lanka. Journal of
Tropical Medicine and Hygiene 1984; 87: 185-187.

13. Zaoui A., Cherrah Y., Mahassini N., Alaoui K., Amarouch H., Hassar M. Acute and chronic toxicity of Nigella sativa fixed oil. Phytomedicine 2002; 9: 69-74.

14. Oliveira M.G.M., Monteiro M.G., Macaubas C., Barbosa V.P., Carlini E.A. Pharmacologic and toxicologic effects of two Maytenus species in laboratory animals. Journal of Ethnopharmacology 1991; 34: 29-41.

15. Joffe J.M. Influence of the drug exposure of the father on perinatal outcome. Clinics in Perinatology 1979; 67: 21-36. 